\title{
A Comparative Research Between Fashion Magazines and Fashion Network Media
}

\author{
Zhao Lunan ${ }^{1, a}$, Jin Shui ${ }^{1, b, *}$ \\ ${ }^{1}$ Business School, Beijing Institute of Fashion Technology, Chaoyang District, Beijing, China \\ a lunastep@163.com, bjinshui@126.com \\ *corresponding author
}

Keywords: Fashion magazines, Fashion network media,WeChat

\begin{abstract}
At present, people are keen to discuss whether the fashion media will replace fashion magazines. Through to compare the status quo, advantages and operational data between fashion media and fashion magazines, I analysed the relationship between them. The conclusion is that the relationship between fashion media and fashion magazines is actually cooperative, competitive and mutual promotion.
\end{abstract}

\section{Introduction}

Recently, a number of fashion magazines have announced layoffs or even closure. In early November 2015, GQ and Glamour what Conde Nast's two fashion magazine has layoffs. Ray, which widespread in China also stopped issuing in January 2016. Many believe that the rise of the Internet has led to a decline in fashion magazines.

I think fashion magazines have an irreplaceable position in fashion industry. And luxury brands are more likely to advertise in fashion magazines. Fashion magazines are also establishing the fashion website, we media, etc., this is a series of moves in order to better adapt to the development of communication. And further meaning is to add energy for subsequent fashion magazines, because network media can better communicate with the audience, promote the footsteps of fashion magazines.

So, only after comparing fashion magazines and fashion media, we can clearly understand the relationship between fashion magazines and network media, more understand we cannot shake the status of the fashion magazines.

\section{Fashion Magazines Overview}

In general, magazines are print media. Print media, as the name implies, that provided a series of news or information to the public by means of paper belong to traditional media. What is fashion magazines after they added fashion? Fashion, sounded starlight and contagious, this concept including all aspects. For example, attractive clothing, the novel modelling, healthy life, art, and so on. Those are part of the Fashion. Those parts of fashion infect people and guide people and gather people, this result will be a trend or popular, that is fashion.

In general, each magazine doesn't have to have a company to run it alone, a group forges a number of magazines together. This group is doing the fashion industry. Now, there are mainly having four fashion industry groups: Fashion group, Hurst group, Conde Nast group, Ruili group.

Fashion group includes many magazines such as Cosmopolitan, Harper's Bazaar, Esquire, FHM, Cosmo Bride, and Basha Jewelry and so on. Hurst group includes ELLE, Marie Claire, FEMINA, ELLEMAN, Psychologies and so on. Conde Nast group includes VOGUE, SELF, GQ and so on. Ruili group includes Rayli, Her Style, Ray Li Home and so on. The characteristics of fashion magazines are mainly reflected in five aspects: Guiding the trend. The layout is rich. The content is advertising. The audience is completely subdivided. The dual sales model. 


\section{Fashion Network Media}

This is the mode of transmission about the spread of a fashion industry based on the development of Internet technology. With Internet technology, it gradually developed from the large PC terminal to the mobile terminal. It spread the popular current information, indoctrination a new way of life, and describes the social fashion environment. Through the use of network cable, $\mathrm{WiFi}$, network traffic and other means, fashion network update speed is extremely fast. The transmission path becomes more comprehensive. Even the individual fashion network media also began to appear in front of public, to provide a clear trend of fashion with beautiful pictures, creative information, and news and so on.

Fashion media according to the different nature of the dissemination can be divided into three categories: fashion channel sites, fashion we media, fashion blog.

Fashion channel sites can be divided into three categories. First, integrated portal channels: Tencent Fashion, Phoenix Fashion, Sina Fashion, NetEase Fashion, Sohu Fashion and so on. The second is the vertical fashion website: HAIBAO, PClady, Style.com, POPSUGAR, etc.. The last one is the fashion magazines' network transplant version: YOKA, Rayli.com, and so on. Fashion we media is the media of the dissemination of independent information by use of Blog, Microblog, WeChat and Instagram and other means. Fashion bloggers are similar with fashion individual media, but the fashion bloggers tend to use the form of pictures to convey the trend of fashion, and to promote the use of various types of goods.

Fashion network media has five characteristics: fast race against time, nifty content, network media combinations, star-based selling point, and the last one is the network media love to make itself as a selling point.

\section{Comparative between Fashion Magazines and Fashion Network Media}

\subsection{Gender Difference}

For fashion magazines, the female version of the publication has a large number of female audiences. The male version of the publication has a large number of female and male audiences. Because women play a care role in the family and often have the right to purchase for the family, so a large part of the female audience wouldn't give up pursuing fashion. For fashion network media, there is no male and female site, so that fashion network media could lose part of male consumers, female audience is also a lot.

\subsection{Age Difference}

For fashion magazines, the reader'age is about 17-40 years old. Many people whose age is over forty years old do not care about the appearance. Fashion has also become an indispensable part of student life. And now high school students and college students have a lot of money in addition to the cost of living given by their parents. They can use their own leisure time to make money, which greatly improved their spending power. For the fashion network media, the age boundary is not as clear as the fashion magazines, but the age group is mainly young people.

\subsection{Professional Characteristics}

For fashion magazines, the reader includes college students, middle class people and higher levels crowd. Most of these people are working in foreign companies, public relations companies, advertising companies and so on, their work is generally bright. They can enhance their professional value through these external dresses up. For fashion network media, it is an open platform, anyone can interest in fashion.

\subsection{Income level}

For fashion magazines, its audience income belongs to a high income level. For fashion network media, the network restriction is small. Network media is an open platform, so covering the audience of the various class levels. 


\subsection{Consumption Custom}

For fashion magazine, the audience has a good purchasing power. They pay attention to brand awareness, pay attention to the quality of life, pay attention to chase the trend. Their own value and spending power are relatively strong. For fashion network media, as long as you want to get information or you have a little interested in fashion, you can browse the page at less cost. So the audience did not have good spending habits.

In summary, the fashion magazines audience significantly more clear than the fashion media audience. In view of the price of tens of Yuan per magazine, two journals monthly, people who are willing to buy magazines are having a certain spending power and lofty Knowledge. General luxury brand attaches great importance to their own brand image; they are more willing to face these middle class people from the fashion magazines. Network platform is so open that it is not suitable for luxury brands. Therefore, luxury advertising revenue in the fashion magazines is still high. Fashion magazines will not be eliminated.

\section{Online Study between Fashion Magazines and Fashion Network Media}

\subsection{WeChat Official Accounts Comparative}

WeChat official accounts can be roughly divided into two categories: fashion magazines vertical official accounts, fashion network media official accounts. The fashion network media WeChat official accounts also contain the fashion website official accounts, the fashion media official accounts and fashion blog official accounts.

According to statistics, fashion WeChat official accounts' article update time is concentrated in $10 \mathrm{am} \sim 12 \mathrm{am}$ and $6 \mathrm{pm} \sim 9 \mathrm{pm} .31 .2 \%$ of the headlines article's reading quantity more than 10,000. The average reading quantity is 13,289 , it reflecting the WeChat users are generally concerned about fashion information.

Table 12015 fashion WeChat official accounts list.

\begin{tabular}{|c|c|c|c|c|}
\hline Name & $\begin{array}{c}\text { Fans number } \\
\text { approximate } \\
\text { number }\end{array}$ & $\begin{array}{c}\text { Headlines } \\
\text { article average } \\
\text { reading } \\
\text { quantity }\end{array}$ & $\begin{array}{c}\text { Article } \\
\text { average } \\
\text { reading } \\
\text { quantity }\end{array}$ & $\begin{array}{c}\text { Average } \\
\text { article } \\
\text { weekly }\end{array}$ \\
\hline COSMO(Magazine) & $1,000,000$ & 82,759 & 40,755 & 4.4 \\
\hline HAIBAO(Network Media) & 960,000 & 66,777 & 32,030 & 3.7 \\
\hline Phoenix Fashion(Network Media) & 900,000 & 51,637 & 30,578 & 4.2 \\
\hline Harper's Bazaar(Magazine) & 750,000 & 33,203 & 18,753 & 3.8 \\
\hline VOGUE CHINA(Magazine) & 700,000 & 30,749 & 17,072 & 3.3 \\
\hline OnlyLady(Network Media) & 610,000 & 29,630 & 13,507 & 5.8 \\
\hline Tencent Fashion(Network Media) & 400,000 & 18,224 & 7,993 & 5.2 \\
\hline ELLE(Magazine) & 350,000 & 28,893 & 10545 & 4.7 \\
\hline StyleTV(Network Media) & 250,000 & 12,412 & 5,033 & 3.0 \\
\hline SELE(Magazine) & 240,000 & 11,032 & 6,125 & 4.6 \\
\hline Marie Claire(Magazine) & 210,000 & 10,122 & 4,837 & 4.6 \\
\hline YOKA(Network Media) & 200,000 & 7,743 & 2,823 & 6.3 \\
\hline GRAZIA(Magazine) & 180,000 & 10,397 & 5.074 & 3.3 \\
\hline OK(Magazine) & 150,000 & 7,822 & 3.605 & 2 \\
\hline Sina Fashion(Network Media) & 90,000 & 2,578 & 1.094 & 3 \\
\hline Netease Fashion(Network Media) & 40,000 & 1,324 & 344 & 4.4 \\
\hline Sohu Fashion(Network Media) & 40,000 & 1,299 & 400 & 4.6 \\
\hline
\end{tabular}

From the Internet published WeChat official accounts advertising effect list point of view, individual we media official accounts' commercial value is much higher than media version official accounts. 


\subsection{Sina Weibo Comparative}

Table 22015 SinaWeibo data.

\begin{tabular}{|c|c|c|c|c|}
\hline Name & $\begin{array}{c}\text { SinaWeibo } \\
\text { value (Yuan) }\end{array}$ & $\begin{array}{c}\text { Fans number } \\
\text { approximate } \\
\text { number }\end{array}$ & $\begin{array}{c}\text { Weibo } \\
\text { number }\end{array}$ & PR \\
\hline Harper's Bazaar & $44,330,000$ & $5,040,000$ & 16,064 & 1.42 \\
\hline ELLE & $10,300,000$ & $2,490,000$ & 33,759 & 1.59 \\
\hline COSMO & $18,070,000$ & $1,980,000$ & 21,006 & 1.93 \\
\hline VOGUE CHINA & $14,300,000$ & $2,430,000$ & 7,171 & 1.4 \\
\hline YOKA & $6,380,000$ & $2,210,000$ & 30,375 & 1.26 \\
\hline PCLADY & $1,320,000$ & 270,000 & 31,073 & 1.6 \\
\hline Sina Fashion & $18,640,000$ & $3,340,000$ & 37,636 & 1.9 \\
\hline
\end{tabular}

PR value is a measure of the quality of the fans; $\mathrm{PR}>1$ shows the quality of fans exceed average quality. From Sina Weibo public data analysis, Harper's Bazaar operating Weibo results the best, no one can go beyond 44.33 million Sina Weibo value; PR value is equal to 1.42 shows the high quality of fans. Through the data we could see, fashion magazines' Sina Weibo value is very high, the quality of fans is also good, the speed of update microblogging is also very timely, indicating that the fashion magazines' Sina Weibo business model be approved by the readers.

\subsection{Content Comparative}

YOKA.com was formally established in May 2006. YOKA belong to Fashion Group. All of its online resources are derived from the Fashion Group's fashion magazines. Sohu Fashion channel is officially launched at the end of March 1999, design content carefully through analyze the reader's needs and market development.

Even if the YOKA' content classification is not clear and its readers difficult to read regularly, but many fashion Group's magazines have a lot of content resources. So the content and authority of YOKA is much better than Sohu Fashion. Even if Sohu fashion was founded earlier than YOKA, but its channel involved so much things that cannot focus on creating fashion industry.

\section{Operation comparison between Fashion Magazines and Fashion Network Media}

\subsection{Network Fashion Bloggers Cooperation with Fashion Magazines}

Popular fashion bloggers can be invited to take photos on the fashion magazines. The emergence of the earliest fashion red people is Choke Mouth Small Pepper. Almost every one of the single product they wear will become popular models. Taobao search page is also appeared a large number of products with keywords "the same style with Choke Mouth Small Pepper"; each product monthly sales are more than a thousand. Fashion magazines also saw a lot of people like them; the Chinese version of VOGUE in July 2010 has done an exclusive interview about them on an internal page with a length of eight pages. Cosmic first fashion blogger Chiara Ferragni in April 2015 boarded the Spanish version of VOGUE cover, the same year, also in July she shooting a group of ultrabeautiful fashion blockbuster for COSMOPOLITAN.

In addition, fashion bloggers also need the help of the fashion magazines. Chiara Ferragni is not only good at taking pictures, but also has its own designer brand. This requires not only do product publicity by themselves, but also with the help of fashion magazines, such as use a single product from the Chiara Ferragni brand to do costume matching on the inside page fashion magazines, and then marked a single product information to achieve the purpose of promotion.

\subsection{Network Fashion Bloggers Compete with Fashion Magazines}

According to "Harper's Bazaar" statistics, brands and designers will spend more than 100 million dollars each year to sponsor fashion bloggers. It is reported that fashion blogger Pink Peonies in Instagram upload her photos to promote merchandise in the 2014 Christmas. This period sales 
were1 million US dollars. In December, Burberry, Ugg, Donna Karen and other brands sold more than 8 million US dollars in sales site, an increase of 315\% over the previous year, most of which credit thanks to the fashion bloggers. Fashion blogger Chiara Ferragni fans number in Instagram can compare with the old fashion magazines VOGUE, so we all know that this is a secret contest.

\section{Conclusion}

Through the comparison between fashion magazines with fashion network media, fashion magazines will not enter this situation that some scholars said "paper media will die". The emergence of network media and the popularity of we media both have a great relationship with fashion magazines, both of them can be mutually beneficial in peace, but also peaceful competition. Fashion magazines group was develop fashion network media business based on the evolution of the means of communication, social development, on the one hand it is built on the basis of a century history of fashion magazines, borrow the resources of fashion magazines; on the other hand the interaction with the reader can promote fashion magazines communication ability and content quality.

Therefore, the relationship between fashion magazines and fashion network media is intimate and inseparable, there is also a benign competition relationship between them. Both of them are aimed at adding new channels of communication based on the maintenance of the old excellent communication channels, the spread of fashion industry meaning is unique and profound.

\section{Acknowledgements}

I would like to express my heartfelt gratitude to my tutor, associate professor Jin Shui, for his constant encouragement and guidance. He has walked me through all the stages of the writing of this thesis. Without his consistent and illuminating instruction, this thesis could not have reached its present form.

\section{References}

[1] Zeyun Zhao. Historical Reflections on Chinese Fashion Magazines[J]. (2011) Journal of International Communication.5, 108-112.

[2] Cheng Chen. The Characteristics and Development Trend of Fashion Magazines[J]. (2010) Sichuan University.

[3] Guoming Yu. Media Economics Tutorial [M]. (2009) China Renmin University Press ,108.

[4] Shuangli Yu. A Study on the Management Strategy of Fashion Magazines in the Context of Media Fusion [J]. (2014) Beijing Jiaotong University.

[5] Huiling Xie, Zheng Li. Independent Magazine in We Media Era[J]. (2011) Editor'sFriend.

[6] Xiaotong Liu. Research on Network Fashion Channel Based on Consumer Culture Visual Field - Taking Sohu Fashion Channel as an Example [J]. (2015) Journal of International Communication.3,28-30. 